\title{
TOURIST SHOPPERS' SATISFACTION WITH REGIONAL MALL EXPERIENCES
}

Melody L. A. LeHew, Kansas State University

Scarlett C. Wesley, University of Kentucky

November 2006

The authors gratefully acknowledge funding of this study by a grant from the International Council of Shopping Centers Educational Foundation. Send correspondence to Melody L. A. Lehew, Kansas State University, College of Human Ecology, Department of Apparel, Textiles, and Interior Design, 217 Justin Hall, Manhattan, Kansas 66502, telephone/fax (785)-532-1321/3796, lehew@humec.ksu.edu. Scarlett C. Wesley, University of Kentucky, College of Agriculture, School of Human Environmental Sciences, Department of Merchandising, Apparel and Textiles, 318 Erikson Hall, Lexington, KY 40506, telephone/fax (859)-257-7778/1275, scarlett.wesley@uky.edu. 
TOURIST SHOPPERS’ SATISFACTION WITH REGIONAL SHOPPING MALL

\title{
EXPERIENCES
}

\author{
Abstract \\ This article assesses whether tourist shopper segments are an attractive market for \\ shopping centers. The purpose of this research is to explore whether or not tourist shoppers are \\ more satisfied than resident shoppers with their shopping experience and do tourist shoppers \\ have the intention to spend more than their resident shopper counterparts. Data for this report \\ come from personal face-to-face mall intercepts of shoppers $(n=578)$ in two new generation \\ malls (West Edmonton Mall and Mall of America in Bloomington) and two heritage-destination \\ (Pier 39 in San Francisco and Forum Shops in Las Vegas) centers. Analysis concludes that \\ although the shopping center and retail industry place increasing emphasis on leisure shopping \\ and tourism, the results of this study suggest that the tourist shopper market may not be the most \\ valuable customer group. Resident shoppers of tourist-focused shopping centers are more \\ satisfied than tourist shoppers of those centers. These findings should encourage shopping \\ center managers to use caution when modifying strategies to meet the needs of the tourist \\ segment, as well as to not forget the importance of resident shoppers to their profitability.
}

Key words: tourism, shopping, shopping centers, customer satisfaction

Shopping is a preferred activity for travelers and the shopping center industry responds by developing new properties or adjusting strategies to encourage patronage by tourist shoppers (Paige \& Litrell, 2003). Examples of large-scale tourist oriented shopping malls currently 
operating include Mall of America and West Edmonton Mall. The Mall of America attracts approximately 43 million visitors per year (Gill, 2007), while the West Edmonton Mall annual visits are around 22 million (Hazel, 2001).

According to the International Council of Shopping Centers (2000), malls are able "to foster the same magical experiences that were once only seen in national amusement parks such as Disney World" (p. 3). Similar to retailers, who are placing increasing emphasis on entertaining customers (Arnold \& Reynolds, 2003; Kruger, 2001; Mazur, 1999; Wilson, 2001), shopping centers recognize that a fun and interesting shopping experience is important (Anonymous, 2000; Ginsberg, 1999; International Council of Shopping Centers, 2000). Large, tourist-focused shopping centers typically include amusement parks, ice skating rinks, water parks, and/or various other entertainment venues as part of their tenant mix. Emphasizing entertainment strategies and shopping as a leisure activity allow shopping centers to broaden their customer base to include tourist shoppers.

The attempt to draw in a tourist oriented customer base appears to be in opposition to the retail industry's increased interest in building customer loyalty (Cuthbertson \& Laine, 2004; Forseter, 2005; Hallowell, 1996; Kumar \& Shah, 2004; LeHew, Burgess \& Wesley, 2002; Macintosh \& Lockshin, 1997; Magi, 2003; Oliver, 1999; Stone \& Bearman, 2004; Wallace \& Giese, 2004). Attracting non-residents to patronize a shopping center encourages a temporary relationship with these customers. In an age where organizations attempt to quantify the lifetime value of a customer, targeting short-term customers appears illogical. Therefore, evaluating whether tourist shoppers may be an attractive market for shopping centers is important. The purpose of this paper is to investigate key differences in shopping satisfaction and behavioral 
intentions between tourist and resident shoppers.

\section{REVIEW OF LITERATURE}

\section{Tourism and Tourist Shopping Behavior}

For travelers, shopping is the number one trip activity for both domestic and international tourists (Goeldner, Ritchie, \& McIntosh, 2000; Kent, Shock, \& Snow, 1983; TIA TravelScope, 2003), and for many a trip is not complete without having spent time shopping (Hudman \& Hawkins, 1989). TIA TravelScope (2003) estimates that $34 \%$ of all trips by U.S. tourists include shopping as an activity. However, the importance of shopping as a tourist activity is not well represented in the literature (Heung \& Cheng, 2000; Law \& Au, 2000).

The travel industry defines persons who travel as visitors (Paci, 1992). These visitors are persons who travel outside their usual environment for leisure, business, or other purposes, at which point the act of traveling becomes tourism (Paci, 1992). Tourism is the activities of people who travel to and stay in places outside their usual environment. Tourists are temporary visitors to a destination (Paci, 1992) and will return to their permanent residencies after traveling.

As traveling increases, so does shopping. With many options available to travelers today, shopping currently accounts for $33 \%$ of all trips taken in the United States, followed by outdoor activities $(17 \%)$, visits to historical sites and museums (14\%), and travel to beaches, cultural events, and festivals, and national/state parks (10\% each), (TIA TravelScope 2003). Tourists are also spending money when they travel. For example, in 2001, General Growth Properties, one of the United States' largest shopping center owners, reports an estimated $31 \%$ of its annual sales came from tourist customers (General Growth Properties Announces, 2001). Similarly, a study 
by the Travel Industry Association of America and Taubman Centers (TIA and Taubman Centers Release, 2001) finds that for more than half (51\%) of U.S. adults traveling named shopping as their primary or secondary reason for travel. Findings also_suggest tourist shoppers spend a lot on their purchases - an average of $\$ 333$ during each trip taken, with $22 \%$ spending more than $\$ 500$ each trip (TIA and Taubman Center Release, 2001).

Tourists like to take something home from the trip (Gordon, 1987), and therefore, they go shopping. A tourist's shopping behavior is very different from his/her normal shopping activity. "They spend money on small foolish items because it is not an ordinary time" (Gordon, 1986, p. 139). As a tourist, a person does not have to think about their job or any other obligations they have at home. The tourist also gains satisfaction from the shopping experience, separate from the purchase of the product (Buttle, 1992; Christiansen \& Snepenger, 2002). Tourist shopping is not limited to souvenirs but also includes purchases of clothing, jewelry, books, arts and crafts, and electronics (Timothy \& Butler, 1995). Typically, tourists do not go shopping with a specific list; rather shopping becomes a by-product of their travel experiences (Thomos \& LeTourneur, 2001). Tourists spend approximately one-third of their total expenditures on shopping purchases (Gratton \& Taylor, 1987; Littrell, Baizerman, Kean, Gahring, Niemeyer, Reilly, \& Stout, 1994) only spending more on their accommodations (Turner \& Reisinger, 2001).

When shopping, tourists base their purchase decisions on several factors. Research finds that tourists look for high-quality, well-designed products (Costello \& Fairhurst, 2002; Littrell, et al., 1994; Paige \& Littrell, 2003; Reisinger \& Turner, 2002). Many tourists will spend more money on purchasing an item while they are away from home, so they want to secure the highest quality item possible. Tourists feel that purchasing an item by a well-known manufacturer is 
very important (Littrell, et al., 1994), and therefore, look to find well-known brand names or logos when shopping (Gee, 1987). These well-known products are brands with which they are familiar; thereby they feel confident in their purchase decisions.

Research shows that tourist shoppers look for unique products unavailable at home or unique to the tourist destination (Costello \& Fairhurst, 2002; Littrell, et al., 1994; Paige \& Littrell, 2003; Reisinger \& Turner, 2002). The unique quality of the product enhances the tourism experience by giving the tourist a special memory about their trip (Turner \& Reisinger, 2001), allowing them to positively reminisce about the experience they had while traveling. However, whether or not this characteristic is generalizable to all shopping formats is questionable. The researchers finding uniqueness to be important to tourist shoppers were looking at shopping in local retail areas versus shopping center settings. Many shopping centers are similar from location to location. Therefore, shoppers of shopping centers may not expect to find unique retail storefronts, but rather are looking for the shops with which they are the most familiar.

\section{Shopping Satisfaction}

The marketing concept suggests that satisfying customers should be the primary goal for firms because satisfaction leads to profitability. "One key measure of whether retailers are fulfilling the marketing concept is that of customer satisfaction" (Ellis, \& Marino, 1992, p. 42). Satisfaction with a shopping experience encourages re-patronage intentions, and customer loyalty (Hallowell, 1996). For retail organizations, whether a retail store or a shopping center with multiple retail tenants, offering appropriate mix of products, services, and experiences enhances customer satisfaction. Brown (1987) identifies relevant attribute categories through 
which retail organizations attempt to satisfy customers: merchandise, service, physical characteristics, employees, and other shoppers (as cited in Ellis \& Marino, 1992). Assessment of customer attitudes relating to such retail attributes allows management to modify strategies and increase shopping satisfaction (Ellis \& Marino, 1992).

As well as satisfaction, respondent's intention to spend money during the current shopping trip is a variable of interest. Research supports the link between satisfaction and profitability (Gomez, McLaughlin, \& Wittink, 2004; Hallowell, 1996). Hallowell (1996) finds that customer loyalty explains nearly forty percent of the variance in profitability. Likewise, customer satisfaction explains thirty-seven percent of differing customer loyalty levels (Hallowell, 1996). Since evidence supports the link between satisfaction and profitability, shopping center strategies increasing tourist shopping satisfaction should result in greater spending by these customers. Tourism research finds tourist shoppers spending more than other shoppers (McCormick, 2002; Travel Industry Association of America, 2001; TIA and Taubman Center Release, 2001). If so, shopping center managers may modify center attributes to increase tourists' satisfaction if they intend to target them as part of the overall marketing strategy.

\section{Research Questions}

1. Are tourist shoppers more satisfied than resident shoppers with their shopping experience?

2. Do tourist shoppers have intention to spend more than resident shoppers?

\section{METHODOLOGY}

Responding to the increasing demand for leisure shopping, centers utilize one of three strategic models: ambient leisure, new generation mall, or heritage-destination leisure (Johnson, 
1990). The ambient leisure model recommends creating a pleasant shopping environment to encourage shoppers to extend their stay in the property (Johnson, 1990). Whereas, the new generation mall (NGM) model calls for the property to become the tourist destination by offering recreational and entertainment attractions as part of the tenant mix (Johnson, 1990). The third possible model, the heritage-destination model, results in a shopping center appealing to both shoppers and sightseers to an existing tourist area (Johnson, 1990). The last two models: new generation mall and heritage-destination leisure, are of interest in this study because they represent shopping centers that target tourists as well as resident shoppers. Therefore, for this study, four North American shopping centers represent the typical centers attracting tourist shoppers: The Mall of America, West Edmonton Mall, The Forum Shops, and Pier 39. The Mall of America and West Edmonton Mall are shopping centers that are travel destinations - new generation malls. These centers draw visitors from around the world. The remaining two centers also attract tourist shoppers, but these centers may not be the primary destination for travelers. The Forum Shops and Pier 39 are centers locating within or nearby very popular travel destinations (Las Vegas, Nevada and San Francisco, California respectively) and classify as heritage-destination centers.

In Bloomington, Minnesota, the Mall of America is the United States' largest retail and entertainment complex, attracting more visitors annually then Disney World (Mall of America Continues Its Nine-Year Reign, 2001). The Mall of America is a major tourist destination with average sales around $\$ 860$ million per year (Lisanti, 1998). Forty percent of customers are tourists, including domestic as well as international visitors (Media: Tourism Media Information, n.d.), attributing approximately fifty percent of gross sales to tourism (Pesmen, 1994). 
The West Edmonton Mall covers 5.3 million square feet of shopping and entertainment space and is currently listed as Alberta's number one tourist attraction (Fast Facts, 2002). Developers of the mall sought to create a mixed shopping and entertainment environment powerful enough to become a major tourist destination (Getz, 1993).

The Forum Shops in Las Vegas, Nevada is one of the earliest shopping-center-as-themepark creations, drawing around $\$ 1,200$ per square foot in annual sales, whereas the national average for per square foot sales is around $\$ 300$ (Ginsburg, 1999). The Forum Shops uniquely simulates ancient Roman streets and connects to Caesar's Palace casino and hotel.

Pier 39 is in San Francisco, California and is San Francisco's number one tourist attraction with approximately 10.5 million visitors each year (Pier 39 Press Priorities, 2002). Located just two blocks from Fisherman's Wharf, Pier 39 provides stunning views of the Golden Gate Bridge, Alcatraz, Angel Island, and the San Francisco Bay (Pier 39 Press Priorities, 2002). Survey Instrument

Items for this study are part of a larger study investigating attribute preferences and shopping orientations of shopping center customers. Customer satisfaction and their intention to spend are of interest in this study, as well as characteristics of the respondents. The questionnaire measures satisfaction using a five-point Likert-type scale. Responses may range from satisfied (1) to dissatisfied (5), with the mid-point (3) representing an undecided response. Two of the satisfaction items measure overall satisfaction with the shopping center. Twelve remaining items focus on respondent satisfaction with various aspects of the shopping center: retailer and merchandise characteristics; service and convenience; and physical characteristics of the center. Spending intentions of the respondents are measured using nominal scales. 
Respondents are asked to choose the category representing their intended level of spending. Choosing only one, respondents select the category they intend to spend the most from a list of typical category measures. The instrument also measures specific characteristics of the respondents, such as whether resident or tourist, frequency of visits, and other demographic details.

\section{DATA COLLECTION}

Shopping center representatives agreed to allow data collection using the mall intercept technique. Researchers were positioned in a central location of each shopping center, and an informational sign detailed the study. Shoppers were asked to participate in the study as they passed by the collection location. Each respondent was given a participation gift after completing the questionnaire. The final convenience sample contained 578 respondents.

\section{Sample Description}

Table 1 presents characteristics of the sample. Females are approximately two-thirds of the sample. Respondents are primarily young, with thirty percent falling in the range of 18 to 24 years old. The next two largest age groups are evenly split between the ranges of 25 to 34 years old (21\%) and 35 to 44 years old (23\%). The sample is predominantly White/Caucasian ethnic origin (75\%). The next largest ethnic group is Asian/Pacific Islander (9\%). Marital status is evenly split between single and married respondents. Thirty-one percent of respondents report completing some college (31\%) and approximately twenty-two percent report completing high school (22\%). Twenty-two percent have a Bachelor's degree (22\%). The demographic characteristics of this sample represent the typical shopper in the new generation malls and heritage-destination centers, but may not hold true in all such shopping centers. The data 
collection method was not random, due to the exploratory nature of the study.

Take in Table 1

\section{DATA ANALYSIS}

Data analysis includes using SAS 9.1 computer software. The data analysis utilizes the 578 usable surveys from the study. If a response item was missing, that respondent was dropped from the analysis. Therefore, overall sample size may vary during the separate analyses.

T-tests analyze the differences between resident and tourist shopper satisfaction. Chisquare tests assess the differences between resident and tourist shoppers' intentions and behaviors. Respondents were asked to identify the amount of money they were planning to spend, their primary reason for visiting the shopping center, as well as the number of times they had visited that center. These items are nominal variables; therefore, chi-square tests are appropriate.

\section{RESULTS and DISCUSSION}

The purpose of this research is to investigate the attractiveness of targeting a tourist market by examining key difference in shopping satisfaction and behavioral intentions. Two research questions were posed: (1) are tourist shoppers more satisfied than resident shoppers with their shopping experience; and (2) do tourist shoppers have intention to spend more than resident shoppers?

Take in Table 2 and Table 3

A significant difference occurs_in shopping satisfaction between resident and tourist shoppers along several satisfaction dimensions (Table 3). Satisfaction is higher among resident versus tourist shoppers in regards to: (1) the ease of locating stores; (2) the number of retail 
stores; (3) the overall convenience of the center; (4) the size of the center; (5) the layout of stores in the center (6) the variety of stores; and (7) the ability to comparison shop in the center. No difference is found in overall satisfaction with the shopping center between resident and tourist shoppers (Table 4). Tourist shoppers are not experiencing greater satisfaction, and according to the satisfaction literature should not be as lucrative a market to target as the satisfied resident shoppers.

\section{Take in Table 4}

Chi-square test results do not show a significant difference in the amount of money that tourist and resident shoppers were planning to spend in the shopping centers (Table 5). The lack of significant Chi-Square statistic suggests that differences found are not great enough to rule out chance. Results indicate that both research questions must be answered in a negative sense: tourist shoppers were not more satisfied with the shopping center and do not intend to spend more money while visiting the center.

\section{Take in Table 5}

To better understand tourist shoppers, two additional questions related to shopping center behavior were asked: (1) what was the primary reason for visiting the center and (2) how often had this particular center been visited in the past? Chi-square results suggest that tourist shoppers are more likely than residents to visit the shopping center for entertainment and socializing, whereas resident shoppers are more likely than tourists to visit for other, nonspecified, reasons (Table 5). The greatest frequency of response to this question was shopping as the primary reason to visit the center for both residents and tourists; no significant difference in shopping motivation of the two groups is found. Resident shoppers are more likely than can 
be expected by chance to be regular customers, with more than five visits to that center. Tourists are more likely to be first time visitors, or to have visited 1 to 5 times.

Tourists may not be the most valuable target market for shopping centers. Each data collection center for this study was a tourist destination (new generation mall) or located within a popular tourist area (heritage-destination center). Even shoppers in tourist focused centers tend to be less satisfied, are not planning to spend significantly more than resident shoppers, are less frequent shoppers, and are primarily motivated to visit the center for entertainment and socializing. Therefore the tourist market may not be the most attractive market for shopping centers in general.

The unexpected results stimulate a desire to better understand tourist shoppers. Therefore, some additional post-hoc tests were conducted by dividing the sample into customers of shopping centers located in a tourist area (heritage-destination center) and customers of centers developed as tourist destinations (new generation mall). Statistical $t$ tests compared the mean scores for satisfaction of respondents in new generation malls (NGM) and heritagedestination centers (HDC) (Table 6 and Table 7). Findings suggest that NGM shoppers are more satisfied than HDC shoppers with almost all of the shopping center attributes. New generation mall shoppers are more satisfied with: (1) the number of retail stores in the center; (2) the number of food retailers in the center; (3) the number of entertainment facilities in the center; (4) prices offered by retailers in the center; (5) the fashionability of merchandise offered in the center; (6) overall convenience of the center; (7) the parking facilities of the center; (8) the size of the center; (9) the layout of the center; (10) the variety of stores in the center; and (11) the ability to comparison shop in the center. New generation mall (Mall of America and West 
Edmonton Mall) shoppers are more satisfied then heritage-destination center (Pier 39 and Forum Shops) shoppers (Table 8).

Take in Table 6 and Table 7 and Table 8

Chi-square tests reveal the differences in shopping intention and behaviors of NGM and HDC shoppers (Table 9). Shoppers in NGMs plan to spend more than HDC shoppers. Sixtyfive percent of shoppers planning to spend $\$ 100$ to $\$ 250$ are respondents from new generation malls (NGM), while only thirty-five percent are heritage-destination (HDC) shoppers. Likewise, those respondents reporting plans to spend over $\$ 250$, sixty-five percent are NGM shoppers and thirty-five percent are HDC shoppers. The significant p-values of the Chi-Square test indicate that the difference is not due to chance.

\section{Take in Table 9}

Primary motivations for visiting the two center types are also significantly different. Of the respondents reporting shopping as their primary motivation for visiting the shopping center, seventy percent are new generation mall shoppers, in comparison to thirty percent being heritage-destination shoppers. The analysis also identifies a difference between the two shopping center types related to the socializing motivation. Those respondents reporting socializing as their primary motive, seventy-seven percent are HDC shoppers, while only twenty-three percent are NGM.

The number of times respondents visit the two shopping center types yields an interesting and significant difference. Chi-square results indicate that NGM shoppers visit these malls more frequently, more than 5 times (73\%), than HDC shoppers visit heritage-destination centers (27\%). Whereas, HDC shoppers are more likely than can be expected by chance to be first time 
visitors of that center (78\%) than NGM shoppers as first time visitors $(22 \%)$.

Respondents' intention to spend the most money on specific category of products/services is the last shopping behavior analysis with a chi-square test (Table 9). New generation mall shoppers plan to spend the most money on apparel and shoes $(76 \%)$ as well as health and beauty care (89\%), more so than heritage-destination center shoppers $(24 \%$ and $11 \%$ respectively). Food and souvenirs are most popular with HDC shoppers. Sixty-three percent of HDC shoppers plan to spend most of their money on food in comparison to thirty-seven percent of NGM shoppers. Whereas, ninety-four percent of HDC shoppers plan to spend the most on souvenirs, while only six percent of NGM shoppers intend to spend their money in this category.

\section{IMPLICATIONS}

The shopping center and retail industry place increasing emphasis on leisure shopping and tourism, but the results of this study suggest that the tourist shopper market may not be the most valuable customer group. Resident shoppers of tourist-focused shopping centers are more satisfied than tourist shoppers of those centers. These findings should encourage shopping center managers to use caution when modifying strategies to meet the needs of the tourist segment, as well as to not forget the importance of resident shoppers to their profitability.

The differences in customer satisfaction and behavioral intention of the two shopping center type customers (NGM and HDC) are interesting. In all cases, specific attributes better satisfy NGM shoppers, with intent to shop and frequency motivating their visits. Since, the primary reason for visiting the center is to shop, perhaps expectations regarding the shopping experience are more defined in the mind of the NGM shopper. Therefore, perceptions of center attributes such as layout, number of retail stores, etc., may meet or exceed their shopping 
expectations. Whereas, HDC shoppers schedule a visit to the center as part of their overall tourist experience and preconceived expectations may not be as well formed.

New generation mall shoppers also appear to be more loyal customers. Significantly more report having visited the Mall of America and West Edmonton Mall more than five times, the highest category for respondents to check. This may reflect greater commitment from resident shoppers, or a combination of resident and tourist shoppers. Future research should identify the characteristics of loyal customers of new generation malls (NGM).

Even though the results of this study do not support the attractiveness of the tourist shopper segment, shopping centers located within tourist destinations should attempt to tailor some of their product/service offerings to please such customers. Heritage-destination center shoppers do buy souvenirs and patronize food establishments, which can add to the profitability of the shopping center. Drawing in the tourist shopper with such offerings may enhance the probability of those shoppers purchasing from other product/service categories.

\section{LIMITATIONS and FUTURE RESEARCH}

The non-random nature of the sample for this study is the primary limitation. Therefore the results are not generalizable to the greater population of tourist focused shopping centers. The responses of each customer are only for those days the researchers collected data as well as

only those respondents in the center that agreed to fill out a survey. Customers over 18 years of age wanting to participate were allowed. Therefore, conclusions are cautionary.

Future research should explore the link between satisfying tourist shoppers and the impact on profitability. Typical satisfaction studies indicate that the path from customer satisfaction to profitability goes through customer loyalty. Are tourist shoppers loyal to 
shopping centers outside of their residential area? What constitutes loyalty for tourist shoppers? How many visits per year are necessary to be considered a loyal tourist shopper? Or does a different path to profitability exist when investigating tourism and shopping behavior?

Additionally, a more thorough investigation of the three strategic models (Johnson, 1990) used by the shopping center industry is necessary. Do successful centers have different attributes among the three models: ambient leisure, new generation mall, and heritagegeneration? What local conditions and characteristics are best for each model? Future research will provide a richer understanding of the tourist-shopping phenomenon and provide shopping center managers with information that can help better satisfy these customers as well as improve their strategic performance.

\section{REFERENCES}

Anonymous (2000). Canadian shopping centres head in new direction: Canadian centres need novelty, "main street" retail to capture youth sales. Canadian Appraiser, 44(1), 33-34.

Arnold, M. J., \& Reynolds, K. E. (2003). Hedonic shopping motivations. Journal of Retailing, 79(2), 77-95.

Brown, D. J. (1978). Assessing retail trade: a review of the customer behavior literature. International Journal of Physical Distribution and Materials Management, 9(3), 122

Buttle, F. (1992). Shopping motives: Constructionists perspective. The service Industries Journal, 12(3), 349-367.

Christiansen, T., \& Snepenger, D. J. (2002). Is it the mood or the mall that encourages tourists to shop? Journal of Shopping Center Research, 9(1), 7-26.

Costello, C. A., \& Fairhurst, A. (2002). Purchasing behavior of tourists towards Tennessee-made 
products. International Journal of Hospitality \& Tourism Administration, 3(3), 7-17.

Cuthbertson, R. \& Laine, A. (2004). The role of CRM within retail loyalty marketing. Journal of Targeting, Measurement \& Analysis for Marketing, 12(3), 290-304.

Ellis, B. \& Marino, P. (1992). A managerial approach for customer satisfaction and fulfillment of the marketing concept. Journal of Applied Business Research, 8(2), 42-47.

Fast Facts. (2002). West Edmonton Mall, from the World Wide Web: http://westedmontonmall.com/info/fastfacts.html.

Forseter, M. (2005, March). It's Not Business, It's Personal. Chain Store Age, 81(3), p. 12.

Gattuso, G. (1994) 'Kiosks build mall loyalty and database', Direct Marketing, 57(6): 26-7.

Gee, C. Y. (1987). Travel related to shopping and financial services. The Travel Industry, 422456.

Getz D. (1993, February). Tourist shopping villages. Tourism Management, 15-26.

General Growth Properties announces new tourism marketing initiative - "America's favorite shopping destinations" (2001, April 17). PR Newswire, Retrieved from the World Wide Web: http://www.findarticles.com/cf 0/m4PRN/2001 April 17/73302563/print.html.

Gill, N.S. (2007). Mall of America available at: http://minneapolis.about.com/cs/attractions/a/mallofamerica.htm (accessed January 12).

Ginsburg, J. (1999), "Xtreme Retailing: Stores Fight the Online Onslaught,” BusinessWeek (December 20): Cover Story.

Goeldner, C. R., Ritchie, J. R. B. \& McIntosh, R. W. (2000). Tourism: Principles, Practices, Philosophies ( $8^{\text {th }}$ ed.), New York: John Wiley.

Gomez, M. I., McLaughlin, E. W., \& Wittink, D. R. (2004). Customer satisfaction and retail 
sales performance: An empirical investigation. Journal of Retailing, 80, 265-278.

Gordon, B. (198). The souvenir: Messenger of the extraordinary. Journal of Popular Culture, 20, 135-146.

Grattan, C. \& Taylor, P. (1987). Leisure and shopping. Leisure Management, 7(3), 29-30.

Hallowell, R. (1996) 'The relationships of customer satisfaction, customer loyalty, and profitability: An empirical study', International Journal of Service Industry Management, 7(4): 27-42.

Hazel, D. (2001), “World's Largest Mall at a Crossroads,” Shopping Centers Today (April 1): http://www/icsc.org/srch/sct/current/sct0400/01/html.

Heung, V. C. S. \& Cheng, E. (2000). Assessing tourists' satisfaction with shopping in the Hong Kong Special Administrative Region of China. Journal of Travel Research, (Spring), 711.

Hudman, L. E. \& Hawkins, D. E. (1989). Tourism in Contemporary Society. Englewood Cliffs need state: Prentice-Hall.

International Council of Shopping Centers (2000), "A Brief History of Shopping Centers," (June): http://www.icsc.org/srch/about/imactofshoppingcenters/briefhistory.html.

Kent, W., Schock, P., \& Snow, R. (1983). Shopping: Tourism's unsung hero(ine). Journal of Travel Research, 21(4), 2-4.

Kruger, R. M. (2001, September). Making Shopping Fun. Retail Merchandiser, 41(9), p. 14-16.

Kumar, V., \& Shah, D. (2004). Building and sustaining profitable customer loyalty for the 21 st century. Journal of Retailing, 80(4), 317-329.

Law, R. \& Au, N. (2000). Relationship modeling in tourism shopping: A decision rules induction 
approach. Tourism Management, 21, 241-249.

LeHew, M. L. A., Burgess, B., \& Wesley, S. (2002). Expanding the loyalty concept to include preference for a shopping mall. International Review of Retail, Distribution and Consumer Research, 12(3), 225-236.

Liezl, E. C. S. (2005, March 16). Mall of Asia: The next shopping paradise. BusinessWorld, p. 28.

Lisanti, T. (1998), “A Mega Mall for the New Millennium,” Discount Store News (September 7): http://findarticles.com/cf_0/m3092/n17_v37/21122322/print.html.

Littrell, M. A., Baizerman, S., Kean, R., Gahring, S., Niemeyer, S., Reilly, R., \& Stout, J.A. (1994). Souvenirs and tourism styles. Journal of Travel Research, 33(1), 3-11.

Deleted: Sourvenirs Macintosh, G. \& Lockshin, L. S. (1997). Retail relationships and store loyalty: a multi-level perspective. International Journal of Research in Marketing, 14(5), 487-97.

Magi, A. W. (2003). Share of wallet in retailing: The effects of customer satisfaction, loyalty cards and shopper characteristics. Journal of Retailing, 79(2), 97-106.

Mazur, L. (1999, April 15). Retailers need to offer fun, not just ease of use. Marketing, 19(1), p. 24.

McCormick, R. R. (2002). Shopping industry. Proceedings of the Travel Industry Association of America's 27 $7^{\text {th }}$ Marketing Outlook Forum, 167-173.

Media: Tourism Media Information (n.d.). Retrieved on July 27, 2005 from http://www.mallofamerica.com/about_the_mall/tourism.aspx

Oliver, R. L. (1999). Whence consumer loyalty? Journal of Marketing, 63, 33-44.

Paci, E. (1992). International issues forum: Common measures of tourism. Conference 
Proceedings, $23^{\text {rd }}$ Annual Conference of the Travel and Tourism Research Association, (June), 14-17.

Paige, R. C. \& Littrell, M.A. (2003). Tourism activities and shopping preferences. Journal of Shopping Center Research, 10(2), 7-25.

Pesmen, S. (1994, December 19). It's a mall world after all. Advertising Age, 65(53), p. 3, 9.

Pier 39 press priorities. (n.d.). Pier 39, from the World Wide Web:

http://www.pier39.com/pier30/english/press/index.html.

PR Newswire (2001a). General Growth Properties announces new tourism marketing initiatives: America's favorite shopping destinations. Available at: www.findarticles.com/cf 0/m4PRN/2001_April_17/73302563/print.html

PR Newswire (2001b). Mall of America continues its nine-year reign as nation's largest mall. Available at: http://findarticles.com/cf_0/m4PRN/2001_August_9?77089383/print.html (accessed August 9).

Reisinger, Y., \& Turner, L. W. (2002). The determination of shopping satisfaction of Japanese tourists visiting Hawaii and the Gold Coast compared. Journal of Travel Research, 41, 167-176.

Stone, M. \& Bearman, D. (2004). The effect of retail customer loyalty schemes - Detailed measurement or transforming marketing? Journal of Targeting, Measurement \& Analysis for Marketing, 12(3), 305-318.

Thomas, I. F., \& LeTourneur, C. (2001, August). Resort retail. UrbanLand, 50-51.

TIA and Taubman Centers release first ever survey on U.S. shopping and travel experience. (2001, April 26). Travel Industry Association of America, from the World Wide Web: 
http://tia.org/Press.

TIA TravelScope (2003). Travel Industry Association of America, http://www.tia.org/tiaweb/travel/domestictravel.asp.

Timothy, D. J., \& Butler, R. W. (1995). Cross border shopping: A North American perspective. Annals of Tourism Research, 22(1), 16-34.

Turner, L. W., \& Reisinger, Y. (2001). Shopping satisfaction for domestic tourists. Journal of Retailing and Consumer Services, 8(1), 15-27.

Wallace, D. W., \& Giese, J. L. (2004). Customer retailer loyalty in the context of multiple channel strategies. Journal of Retailing, 80(4), 249-263.

Wilson, M. (2001, March). Redefining retailtainment. Chain Store Age, 77(3)pp. 71-74. 
$\underline{\text { Table 1. Description of Sample }}$

\begin{tabular}{|c|c|c|c|}
\hline & Frequency & Percent & $\mathrm{N}$ \\
\hline Gender & & & 573 \\
\hline Female & 376 & 65.62 & \\
\hline Male & 197 & 34.38 & \\
\hline Age & & & 575 \\
\hline $18-24$ & 177 & 30.78 & \\
\hline $25-34$ & 123 & 21.39 & \\
\hline $35-44$ & 134 & 23.30 & \\
\hline $45-54$ & 78 & 13.57 & \\
\hline $55-64$ & 41 & 7.13 & \\
\hline $65-74$ & 15 & 2.61 & \\
\hline $75+$ & 7 & 1.21 & \\
\hline Ethnic Origin & & & 574 \\
\hline African American & 20 & 3.38 & \\
\hline American Indian/Eskimo & 6 & 1.04 & \\
\hline Asian/Pacific Islander & 52 & 9.04 & \\
\hline Hispanic & 44 & 7.65 & \\
\hline White & 429 & 74.61 & \\
\hline Other & 23 & 4.00 & \\
\hline Marital Status & & & 578 \\
\hline Never Married & 244 & 42.21 & \\
\hline Married & 279 & 48.27 & \\
\hline Divorced & 45 & 7.79 & \\
\hline Widowed & 10 & 1.73 & \\
\hline Education Level & & & 577 \\
\hline Grade School & 34 & 5.89 & \\
\hline High School/GED & 124 & 21.49 & \\
\hline Some College & 178 & 30.85 & \\
\hline Associate's Degree & 40 & 6.93 & \\
\hline Bachelor's Degree & 126 & 21.84 & \\
\hline Graduate/Professional & 75 & 13.00 & \\
\hline
\end{tabular}

Note: Total sample size varies due to missing data. 
Table 2. Mean Satisfaction of Resident and Tourist Shoppers ( $1=$ Satisfied, 5=Dissatisfied)

\begin{tabular}{lcc}
\hline Variable & $\begin{array}{c}\text { Resident } \\
\text { Mean }\end{array}$ & $\begin{array}{l}\text { Tourist } \\
\text { Mean }\end{array}$ \\
\hline Ease of locating stores & 1.91 & 2.23 \\
Number of retail stores & 1.52 & 1.83 \\
Number of food retailers & 1.72 & 1.86 \\
Number of entertainment facilities & 1.73 & 1.92 \\
Prices offered by retailers & 2.67 & 2.83 \\
Fashionability of merchandise & 1.83 & 2.04 \\
Overall convenience & 1.73 & 1.98 \\
Parking facilities & 2.20 & 2.40 \\
Size of center & 1.57 & 1.84 \\
Layout of center & 1.75 & 1.95 \\
Variety of stores & 1.70 & 1.91 \\
Ability to comparison shop & 2.02 & 2.48 \\
Experience in center today & 1.66 & 1.77 \\
When think of center I am: & 1.74 & 1.86 \\
\hline
\end{tabular}


Table 3. Comparison of Resident and Tourist Satisfaction Using a t-Test: Individual Items

\begin{tabular}{llll}
\hline Variable & $\mathrm{t}$ value & $\mathrm{df}$ & $\operatorname{Pr}>|\mathrm{t}|$ \\
\hline Ease of locating stores & -2.83 & 330 & 0.005 \\
Number of retail stores & -2.99 & 325 & 0.003 \\
Number of food retailers & -1.23 & 332 & 0.219 \\
Number of entertainment facilities & -1.78 & 325 & 0.077 \\
Prices offered by retailers & -1.24 & 332 & 0.215 \\
Fashionability of merchandise & -1.90 & 331 & 0.058 \\
Overall convenience & -2.34 & 333 & 0.020 \\
Parking facilities & -1.40 & 319 & 0.161 \\
Size of center & -2.78 & 333 & 0.006 \\
Layout of center & -1.95 & 330 & 0.053 \\
Variety of stores & -2.02 & 332 & 0.044 \\
Ability to comparison shop & -3.79 & 331 & 0.000 \\
Experience in center today & -1.16 & 328 & 0.247 \\
When think of center I am: & -1.32 & 327 & 0.186 \\
\hline
\end{tabular}

Table 4. Comparison of Resident and Tourist Satisfaction Using t-Test: Summed Items

\begin{tabular}{llll}
\hline Variable & $\mathrm{t}$ value & $\mathrm{df}$ & $\operatorname{Pr}>|\mathrm{t}|$ \\
\hline Center attribute satisfaction & -2.66 & 285 & 0.008 \\
Overall satisfaction & -1.40 & 320 & 0.163 \\
\hline
\end{tabular}


Table 5. Chi-Square Test: Shopping Intention and Behavior of Tourist and Resident Shoppers

\begin{tabular}{|c|c|c|c|c|}
\hline & $\mathrm{N}$ & $\begin{array}{l}\text { Resident } \\
\mathrm{n}(\%)\end{array}$ & $\begin{array}{c}\text { Tourist } \\
\mathrm{n}(\%)\end{array}$ & $\begin{array}{l}\text { Total Sample } \\
\quad \%\end{array}$ \\
\hline $\begin{array}{l}\text { Amount of money plan to spend } \\
{\left[\chi^{2}=6.19, \mathrm{df}=3, \mathrm{p}=.103\right]}\end{array}$ & 332 & & & \\
\hline$\$ 1-\$ 50$ & & $78(52.7)$ & $70(47.3)$ & 44.6 \\
\hline$\$ 51-\$ 100$ & & $31(20.4)$ & $48(60.8)$ & 23.8 \\
\hline$\$ 100-\$ 250$ & & $25(37.3)$ & $42(62.7)$ & 20.2 \\
\hline$\$ 251+$ & & $18(47.4)$ & $20(52.6)$ & 11.5 \\
\hline $\begin{array}{l}\text { Primary reason for visiting center } \\
{\left[\chi^{2}=16.94, \mathrm{df}=4, \mathrm{p}=.002\right]}\end{array}$ & 251 & & & \\
\hline Shopping & & $51(44.0)$ & $65(56.0)$ & 46.2 \\
\hline Entertainment & & $16(24.2)$ & $50(75.8)$ & 26.3 \\
\hline Eating & & $7(50.0)$ & $7(50.0)$ & 5.6 \\
\hline Socializing & & $8(34.8)$ & $15(65.2)$ & 9.2 \\
\hline Other & & $21(65.6)$ & $11(34.4)$ & 12.8 \\
\hline $\begin{array}{l}\text { Number times visited the center } \\
{\left[\chi^{2}=186.26, \mathrm{df}=2, \mathrm{p}=.0001\right]}\end{array}$ & 339 & & & \\
\hline First visit & & $3(4.3)$ & $67(95.7)$ & 20.7 \\
\hline 1 to 5 times & & $10(10.8)$ & $83(89.3)$ & 27.4 \\
\hline More than 5 times & & $144(81.8)$ & $32(18.2)$ & 51.9 \\
\hline
\end{tabular}


Table 6. Mean Satisfaction of New Generation Mall (NGM) and Heritage-Destination (HDC) Center Shoppers (1=Satisfied, 5=Dissatisfied).

\begin{tabular}{lll}
\hline Variable & NGM & HDC \\
& Mean & Mean \\
\hline Ease of locating stores & 2.07 & 2.06 \\
Number of retail stores & 1.61 & 1.92 \\
Number of food retailers & 1.65 & 1.98 \\
Number of entertainment facilities & 1.66 & 2.14 \\
Prices offered by retailers & 2.51 & 2.84 \\
Fashionability of merchandise & 1.76 & 2.15 \\
Overall convenience & 1.73 & 2.02 \\
Parking facilities & 1.93 & 2.66 \\
Size of center & 1.51 & 1.96 \\
Layout of center & 1.70 & 2.03 \\
Variety of stores & 1.60 & 1.98 \\
Ability to comparison shop & 2.02 & 2.48 \\
Experience in center today & 1.61 & 1.86 \\
When think of center I am: & 1.60 & 1.97 \\
\hline
\end{tabular}


Table 7. Comparison of New Generation Mall (NGM) and Heritage-Destination (HDC)

Center Satisfaction Using t-Test: Individual Items

\begin{tabular}{lccc}
\hline Variable & $\mathrm{t}$ value & $\mathrm{df}$ & $\operatorname{Pr}>|\mathrm{t}|$ \\
\hline & & & \\
Ease of locating stores & 0.08 & 562 & 0.939 \\
Number of retail stores & -3.88 & 550 & 0.000 \\
Number of food retailers & -4.09 & 562 & 0.000 \\
Number of entertainment facilities & -6.17 & 549 & 0.000 \\
Prices offered by retailers & -3.32 & 560 & 0.001 \\
Fashionability of merchandise & -4.65 & 563 & 0.000 \\
Overall convenience & -3.67 & 563 & 0.000 \\
Parking facilities & -6.89 & 548 & 0.000 \\
Size of center & -6.08 & 566 & 0.000 \\
Layout of center & -4.41 & 562 & 0.000 \\
Variety of stores & -4.94 & 563 & 0.000 \\
Ability to comparison shop & -5.06 & 561 & 0.000 \\
Experience in center today & -3.34 & 554 & 0.001 \\
When think of center I am: & -5.08 & 559 & 0.000 \\
\hline
\end{tabular}

Table 8. Comparison of New Generation Mall (NGM) and Heritage-Destination Center Satisfaction Using t-Test: Summed Items

\begin{tabular}{llll}
\hline Variable & $\mathrm{t}$ value & $\mathrm{df}$ & $\operatorname{Pr}>|\mathrm{t}|$ \\
\hline Center attribute satisfaction & -5.87 & 487 & 0.000 \\
Overall satisfaction & -4.71 & 545 & 0.000 \\
\hline
\end{tabular}


Table 9. Chi-Square Test: Shopping Intention and Behavior of New Generation Mall (NGM) and Heritage-Destination Center (HDC) Shoppers

\begin{tabular}{|c|c|c|c|c|}
\hline & $\mathrm{N}$ & $\begin{array}{c}\text { NGM } \\
\mathrm{n}(\%)\end{array}$ & $\begin{array}{l}\mathrm{HDC} \\
\mathrm{n}(\%)\end{array}$ & $\begin{array}{c}\text { Total Sample } \\
(\%)\end{array}$ \\
\hline $\begin{array}{l}\text { Amount of money plan to spend } \\
{\left[\chi^{2}=20.54, d f=3, p=.0001\right]}\end{array}$ & 568 & & & \\
\hline$\$ 1-\$ 50$ & & $102(45.1)$ & $124(54.9)$ & 39.8 \\
\hline$\$ 51-\$ 100$ & & $63(45.3)$ & $76(54.7)$ & 24.5 \\
\hline$\$ 100-\$ 250$ & & $84(65.1)$ & $45(34.9)$ & 22.7 \\
\hline$\$ 251+$ & & $48(64.9)$ & $26(35.1)$ & 13.0 \\
\hline $\begin{array}{l}\text { Primary reason for visiting center } \\
{\left[\chi^{2}=47.82, \mathrm{df}=4, \mathrm{p}=.0001\right]}\end{array}$ & 441 & & & \\
\hline Shopping & & $161(70.0)$ & $69(30.0)$ & 52.2 \\
\hline Entertainment & & $37(40.7)$ & $54(59.3)$ & 20.6 \\
\hline Eating & & $11(40.7)$ & $16(59.3)$ & 6.1 \\
\hline Socializing & & $9(23.1)$ & $30(76.9)$ & 8.8 \\
\hline Other & & $26(48.2)$ & $28(51.9)$ & 12.2 \\
\hline $\begin{array}{l}\text { Number times visited the center } \\
{\left[\chi^{2}=110.96, d f=2, p=.0001\right]}\end{array}$ & 576 & & & \\
\hline First visit & & $24(21.8)$ & $86(78.2)$ & 19.1 \\
\hline 1 to 5 times & & $58(35.4)$ & $106(64.6)$ & 28.5 \\
\hline More than 5 times & & $220(72.9)$ & $82(27.2)$ & 52.4 \\
\hline $\begin{array}{l}\text { Plan to spend most money on: } \\
{\left[\chi^{2}=63.51, \mathrm{df}=7, \mathrm{p}=.0001\right]}\end{array}$ & 470 & & & \\
\hline Apparel/Shoes & & $120(76.4)$ & $37(23.6)$ & 33.4 \\
\hline Jewelry/Accessories & & $10(52.6)$ & $9(47.4)$ & 4.0 \\
\hline Hobbies/Toys & & $14(51.9)$ & $13(48.2)$ & 5.7 \\
\hline Food & & $41(36.9)$ & $70(63.1)$ & 23.6 \\
\hline Gifts/Collectibles & & $46(57.5)$ & $34(42.5)$ & 17.0 \\
\hline Health/Beauty care & & $8(88.9)$ & $1(11.1)$ & 1.9 \\
\hline Souvenirs & & $1(6.3)$ & $15(93.8)$ & 3.4 \\
\hline Entertainment attractions & & $28(54.9)$ & $23(45.1)$ & 10.9 \\
\hline
\end{tabular}

Note: $\mathrm{N}$ varies due to missing data 